READINGS IN STRATEGIC MANAGEMENT 
This reader is one part of an Open University integrated teaching system and the selection is therefore related to other material available to students. It is designed to evoke the critical understanding of students. Opinions expressed in it are not necessarily those of the course team or of the University. 


\section{READINGS IN STRATEGIC MANAGEMENT}

Edited by

David Asch

School of Management

Open University

and

Cliff Bowman

School of Management

Cranfield Institute of Technology 
Selection and editorial material (C) The Open University 1989

Softcover reprint of the hardcover 1st edition 1989 978-0-333-51793-2

All rights reserved. No reproduction, copy or transmission of this publication may be made without written permission.

No paragraph of this publication may be reproduced, copied or transmitted save with written permission or in accordance with the provisions of the Copyright Act 1956 (as amended), or under the terms of any licence permitting limited copying issued by the Copyright Licensing Agency, 33-4 Alfred Place, London WC1E 7DP.

Any person who does any unauthorised act in relation to this publication may be liable to criminal prosecution and civil claims for damages.

First published 1989

Published by

MACMILLAN EDUCATION LTD

Houndmills, Basingstoke, Hampshire RG21 2XS

and London

Companies and representatives

throughout the world

British Library Cataloguing in Publication Data

Readings in strategic management.

1. Corporate planning

I. Asch, David C. II. Bowman, Cliff

658.4'012

ISBN 978-0-333-51809-0 ISBN 978-1-349-20317-8 (eBook)

DOI 10.1007/978-1-349-20317-8 


\section{Contents}

List of figures

ix

List of tables

xi

Preface

xiii

Acknowledgements

xvii

\section{PART I STRATEGIC MANAGEMENT PROCESSES}

Introduction

2

1 Of Strategies, Deliberate and Emergent Henry Mintzberg and James $A$. Waters

2 Managing Strategic Change James Brian Quinn

3 Rethinking Incrementalism Gerry Johnson

4 Paralysis by Analysis: Is Your Planning System Becoming Too Rational?

R. T. Lenz and Marjorie A. Lyles

5 Strategic Planning for the World Wildlife Fund

G. J. Medley

6 Corporate Strategy and the Small Firm Sue Birley

\section{PART II STRATEGY FORMULATION}

Introduction

7 Does Strategic Planning Improve Company

Performance?

Gordon E. Greenley 
vi Contents

8 Business Policy Formulation: Understanding the Process

Ron McLellan and Graham Kelly

9 Whatever Happened to Environmental Analysis?

Jack L. Engledow and R. T. Lenz

10 How Competitive Forces Shape Strategy

Michael E. Porter

11 Portfolio Planning: Uses and Limits

Philippe Haspeslagh

12 Defining Corporate Strengths and Weaknesses Howard H. Stevenson

13 The Risky Business of Diversification

Ralph Biggadike

14 Assessing Opportunities for Diversification:

An Analytical Approach

Michael Younger

15 An Introduction to Divestment: The Conceptual

Issues

John Coyne and Mike Wright

16 End-game Strategies for Declining Industries

Kathryn Rudie Harrigan and Michael E. Porter

17 From Competitive Advantage to Corporate Strategy Michael E. Porter

18 The Use of Corporate Planning Models: Past, Present and Future Jae K. Shim and Randy McGlade

19 Business Ethics: Two Introductory Questions Tom Sorell

20 Strategy and Ethics: Pilkington PLC

Tom Sorell

Introduction 292

21 Choosing Strategies for Change 
22 Strategy Implementation versus Middle Management Self-interest

William D. Guth and Ian C. MacMillan

23 The Structuring of Organizations Henry Mintzberg

24 Configurations of Strategy and Structure:

Towards a Synthesis

Danny Miller

25 Evolution and Revolution as Organizations Grow 373 Larry E. Greiner

26 Successfully Implementing Strategic Decisions Larry D. Alexander

27 Strategic Control: An Overview of the Issues David Asch

28 The Nature and Use of Formal Control Systems for Management Control and Strategy Implementation

Richard L. Daft and Norman B. Macintosh

388

Index 


\section{List of figures}

1.1 Types of strategies

1.2 Strategic learning $\quad 18$

3.1 A pattern of strategy development $\quad 39$

3.2 The cultural web of an organization 46

3.3 A pattern of problem resolution and strategy formulation 49

3.4 A notional pattern of incremental change 50

3.5 Incremental change and 'strategic drift' 51

4.1 Organizational and technical forces contributing to over-rationalized planning $\quad 59$

5.1 WWF UK net funds $\quad 76$

5.2 WWF UK income per employee - productivity 76

8.1 Alpha process 104

$\begin{array}{lll}8.2 & \text { Beta process } & 105\end{array}$

8.3 Gamma process 106

8.4 Delta process 107

9.1 Summary of role and form changes 122

10.1 Forces governing competition in an industry 134

12.1 Factors which influence a manager in defining strengths and weaknesses

12.2 Criteria used to judge an attribute 173

14.1 Analytical system for selecting sectors 193

14.2 System for appropriateness of a sector to a company's strengths-mesh

14.3 System for overall assessment of sectors 198

14.4 Selection of sectors based on alternative strategies for business development

15.1 Route to adaptation through ownership change 212

16.1 Strategies for declining businesses 230

18.1 Typical structure of a corporate planning model 263

23.1 The six basic parts of the organization 323

23.2 The basic mechanisms of co-ordination 325

23.3 Structures to deal with residual interdependencies 333 
23.4 A permanent matrix structure in an international firm

23.5 Shifting matrix structure in the NASA weather satellite program

23.6 Six types of decentralization

23.7 Six pulls on the organization

23.8 The simple structure

23.9 The machine bureaucracy

23.10 The professional bureaucracy 348

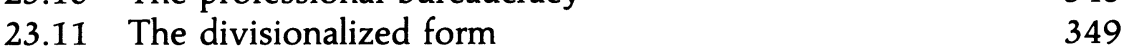

23.12 The adhocracy

23.13 The missionary

351

24.1 Five successful configurations of strategy 360

25.1 Model of organization development $\quad 375$

$\begin{array}{ll}25.2 & \text { The five phases of growth } \\ 27.1 & 378\end{array}$

$\begin{array}{ll}27.1 & \text { A simple control model }\end{array}$

28.1 Average managerial ranking of management control subsystem use for five control functions

28.2 Model of vertical linkage among control systems for strategy implementation 


\section{List of tables}

1.1 Summary description of types of strategies

5.1 WWF UK key areas 1978

16

7.1 Comparison of surveys (i) 89

7.2 Comparison of surveys (ii) 97

9.1 Organizational roles of environmental analysis units $\quad 118$

9.2 Changes in role and form in ten environmental analysis units

120

12.1 Steps in the process of assessing strengths and weaknesses

12.2 Categories for assessing strengths and weaknesses

12.3 The relative importance of attributes identified as strengths and weaknesses (all managers)

164

165

166

12.4 The attributes examined in relation to the companies studied

167

12.5 Attributes of common concern to the companies studied

12.6 The relationship between the category of attribute examined and the manager's organizational level

12.7 Percentage of responses identifying category as a strength at each organizational level

12.8 The association of specific criteria with identification of strengths and weaknesses

168

170

171

172

13.1 Financial performance in the first four years of operations 179

13.2 Operating and capital ratios in the first four years of operations

13.3 Median performance in start-up, adolescent, and mature stages

13.4 Relationship between financial and market performance

13.5 Financial performance and change in relative share, first four years

180

182

185

186

187

13.6 Distribution of sample on entry scale, first two years

13.7 Performance by index of entry scale, first two years 
xii List of Tables

14.2 System for classifying sectors according to degree of maturity

14.3 Scoring system for sector maturity 195

15.1 Spectrum of divestment 203

15.2 Divestment change and breakdown in key areas 207

16.1 Structural factors that influence the attractiveness of declining industry environments

226

17.1 Concepts of corporate strategy

18.1 Results of surveys for the use of corporate planning models

18.2 Applications of corporate planning models 259

18.3 Reasons for discontinuing models 262

18.4 Success factors in modelling 265

21.1 Methods for dealing with resistance to change 302

21.2 Strategic continuum 303

23.1 Basic dimensions of the six configurations 344

24.1 Representative strategic variables within each dimension 357

24.2 Structure, environments and strategies 362

24.3 Matching strategy and structure 364

25.1 Organization practices during evolution in the five phases of growth

26.1 Types of strategic decisions implemented 389

26.2 Ten most frequent strategy implementation problems 390

28.1 Management control system frequency size and cycles 415

28.2 Relationship of management control cycle to MCS and personal control 


\section{Preface}

'Strategic management is the process of making and implementing strategic decisions ... (it) is about the process of strategic change' (Bowman and Asch, 1987, p. 4). This general definition of strategic management conforms with that of most texts in the field (for example, Jauch and Glueck, 1988, p. 5, and Johnson and Scholes, 1988, p. 10). The task of strategic management involves both top management and managers at all levels in the organization. Readers will probably be aware that strategic management is sometimes referred to as corporate strategy, business policy, management policy and organizational policy, which all deal with the same general area of study.

Strategic management affects all parts of the organization. Strategic decisions concern the scope of an organization's activities. That is, should the organization focus on one type of activity, or should it encompass many different types? Strategic management is also concerned with matching of the organization to the environment in which it operates. Accordingly, management will need to consider what threats or opportunities exist, or may exist in the future, in order to position the entity appropriately. Linked closely with this is the need to understand the organization's own capabilities. The availability of resources (people, technology and finance for example) to meet environmental discontinuities and change is fundamental to the organization's strategic development. Strategic decisions are, therefore, likely to have a significant impact on the organization's resources. This may involve disposal or acquisition of resources, or it may involve major changes to the financial structure of the organization. Then again strategic decisions could have a major influence on working patterns and the skills and abilities required of the employees. The way in which an organization develops will also be a function of how managers view their world, the power relationships within the organization, and how the organization is structured and controlled.

The Bradford studies of decision making identified a number of issues concerning strategic decisions (Hickson et al., 1986). They found that strategic decisions themselves tend to be less frequent and more non- 
routine than most other decisions, and are, therefore, comparatively novel (pp. 26-54). There will be few if any precedents for them, yet they are likely to set precedents for subsequent decisions. Strategic decisions commit substantial resources and are organization-wide in their consequences. The most frequent decision topics were those concerning technologies (to re-equip, rebuild), reorganizations, followed by controls (making of plans, the fixing of budgets, commitments on data processing equipment), and domain or market type decisions (price, distribution, image).

The challenge of strategic management is in the involvement of managers in guiding the future direction of the organization. They need, therefore, to understand the complexity deriving from the need both to adopt a strategic perspective, as opposed to a functional or specialist or technical view, and to understand and appreciate the subtlety, inconsistency, bureaucracy, political machinations and the imperatives of the world in which the organization operates. Realistically, we should recognize this complexity and avoid a simplistic approach. Consequently, our selection of readings is intended to illustrate the complex world of the strategic development of organizations so that readers can develop and enhance their own approach to the subject. In conclusion, a single paradigm is not appropriate. We need to recognize that different skills and techniques are required in a dynamic and innovative organization as opposed to those required in a bureaucracy. Strategic management deals with both the uncertain and the unknowable. So, in addition to analysis, managers rely on accumulated experience - a 'feel' for the situation, or intuition. As a result, the paramount indispensable attribute is good judgment which should underlie every decision and action (see, for example, Quinn et al., 1988).

We have selected and structured this collection of readings to reflect the broad and diverse nature of the developing field of strategic management. The wide variety of issues associated with both the theoretical and the practical development of the subject are presented through this range of articles. By virtue of the nature of the subject, some of the papers offer contradictory views. We believe this to be a strength in that it enables a critical examination to be made of the different perspectives arising from differing contexts. Each of the three parts contains papers which develop the conceptual framework of strategic management as well as pieces reporting on the findings of empirical research. We have included some papers with a very prescriptive or normative view of strategic management and some which seek to describe strategic management in practice. There is no one best way in management, so no prescription works for all organizations. Normative concepts have been included where we believe they offer some under- 
standing of the complexity of organizational strategy and where they are associated with other readings or empirical evidence of their use.

We have selected these articles because we believe that they contribute to our understanding of strategic management, or some aspect thereof, better than other articles. Some articles are new, some are older, three have been written specifically for this collection. In order to present a wide variety of good ideas we have edited each of the previously published papers. This has often involved the elimination of interesting examples and/or the detailed methodologies used. In so doing, we have endeavoured to ensure that the key messages have been retained in as concise a manner as possible.

Part I is concerned with strategic management processes. Inherent in it is the view that strategic management is more than corporate or strategic planning. Indeed, corporate planning may be a part of, or element in, the strategy process. In these articles we seek to reflect the differing approaches to the subject as a management process. We believe that an appreciation of the process by which strategic decisions are made is fundamental to understanding why and how such decisions are arrived at. Some knowledge of the process may also help us to grapple with the realities and complexities involved in formulating policy and managing strategic change. Because strategic management is relevant to all types of organization, this part of the collection includes an article on small firms and another on a non-profit-making organization. Part I provides an important perspective on our view of both strategy formulation and the management of strategic change and is crucial to our understanding of the contexts in which these activities take place.

Strategy formulation, Part II, focuses on strategic analysis. The readings concentrate on analysis of the organization in terms of internal and external features, a consideration of strategic options plus a view of the issues involved in the selection of an appropriate strategic alternative. Also included in Part II are two papers on business ethics which we believe raise some interesting issues for the reader to consider as part of developing an understanding of strategy formulation. The number of contributions in this section reflects the fact that it is arguably the most developed part of the literature. Its size also reflects the breadth of the subject matter.

The final section, Part III, is concerned with managing strategic change. This part has contributions on strategy implementation, strategic control and strategy and structure. The management of strategic change concerns issues involved in translating the formulated, often well articulated, strategies into action plans. The articles span a range of interrelated topics from strategic control to power relationships to the stages of growth in organizations. Given the iterative nature of what can 
xvi Preface

be a very complex process, it may not always be appropriate to distinguish formulation and implementation of strategy quite so neatly. Reality is likely to be much more confused, complex and messy.

\section{References}

Bowman, C. and Asch, D. (1987) Strategic Management (London: Macmillan). Hickson, D. J., Butler, R. J., Cray, D., Mallory, G. R. and Wilson, D. C. (1986) Top Decisions: Strategic Decision-Making in Organizations (Oxford: Blackwell). Jauch, L R. and Glueck, W. F. (1988) Business Policy and Strategic Management (New York: McGraw Hill) 5th edn.

Johnson, G. and Scholes, K. (1988) Exploring Corporate Strategy (London: Prentice Hall) 2nd edn.

Quinn, J. B., Mintzberg, H. and James, R. M. (1988) The Strategy Process: Concepts, Contexts, and Cases (Englewood Cliffs, NJ: Prentice Hall). 


\section{Acknowledgements}

The authors and publishers wish to thank the following who have kindly given permission for the use of copyright material.

Harvard Business Review for excerpts from articles from various issues of Harvard Business Review.

Journal of General Management for articles extracted from S. Birley, 'Corporate Strategy and the Small Firm', Journal of General Management, vol. 8, no. 2, Winter 1982-3, pp. 82-6; and R. McLellan and G. Kelly, 'Business Policy Formulation: Understanding the Process', Journal of General Management, Autumn 1980, pp. 38-47.

The Open University for article by D. Asch, 'Strategic Control: An Overview of the Issues', 1988.

Pergamon Press plc for articles extracted from R. T. Lenz and M. A. Lyles, 'Paralysis by Analysis: Is Your Planning System Becoming too Rational?', Long Range Planning, vol. 18, no. 4, 1985, pp. 64-72; G. J. Medley, 'Strategic Planning for the World Wildlife Fund', Long Range Planning, vol. 21, no. 1, 1988, pp. 46-54; G. Greenley, 'Does Strategic Planning Improve Company Performance?', Long Range Planning, vol. 19, no. 2, 1986, pp. 101-9; J. Engledow and R. T. Lenz, 'Whatever Happened to Environmental Analysis?', Long Range Planning, vol. 18, no. 2, 1985, pp. 93-106; M. Younger, 'Assessing Opportunities for Diversification', Long Range Planning, vol. 17, no. 4, 1984, pp. 10-15; L. D. Alexander, 'Successfully Implementing Strategic Decisions', Long Range Planning, vol. 18, no. 3, 1985, pp. 91-7; J. K. Shim and R. Glade, 'The Use of Corporate Planning Models: Past, Present and Future', Journal of the Operational Research Society, vol. 35, no. 10, 1984, pp. 885-93.

Philip Allan Publishers Ltd for J. Coyne and M. Wright, 'An Introduction to Divestment: The Conceptual Issues', from Coyne and Wright (eds), Divestment and Strategic Change, 1985, ch. 1, pp. 1-26.

Prentice Hall, Inc. for material extracted from $\mathrm{H}$. Mintzberg, The Structuring of Organisations, 1979. 
Sloan Management Review for articles extracted from J. B. Quinn, 'Managing Strategic Change', Sloan Management Review, Summer 1980, pp. 3-20; and H. H. Stevens, 'Defining Corporate Strengths and Weaknesses', Sloan Management Review, Spring 1976, pp. 51-68.

Tom Sorell for papers 'Business Ethics': Two Introductory Questions', 1988, and 'Strategy and Ethics: Pilkington PLC', 1988.

Southern Management Association for article extracted from R. E. Daft and N. B. Macintosh, 'The Nature and Use of Formal Central Systems for Management Control and Strategy Implementation', Journal of Management, vol. 10, no. 1, 1984, pp. 43-66.

John Wiley \& Sons Ltd for articles extracted from H. Mintzberg and J. H. Waters, 'Of Strategies Deliberate and Emergent', Strategic Management Journal, vol. 6, 1985, pp. 257-72; G. Johnson, 'Rethinking Incrementalism', Strategic Management Journal, vol. 9, 1988, pp. 75-91; W. D. Guth and I. C. MacMillan, 'Strategy Implementation versus Middle Management Self Interest', Strategic Management Journal, vol. 7, 1986, pp. 31327; D. Miller, 'Configurations of Strategy and Structure: Towards a Synthesis', Strategic Management Journal, vol. 7, 1986, pp. 233-49.

Every effort has been made to trace all the copyright-holders, but if any have been inadvertently overlooked the publishers will be pleased to make the necessary arrangement at the first opportunity. 